\title{
Article
}

\section{Effects of Asymmetric Information on Market Timing in the Mutual Fund Industry}

Tchamyou, Venessa S., Asongu, Simplice A. and Nwachukwu, Jacinta Chikaodi

Available at http://clok.uclan.ac.uk/24994/

Tchamyou, Venessa S., Asongu, Simplice A. and Nwachukwu, Jacinta Chikaodi ORCID: 0000-0003-2987-9242 (2018) Effects of Asymmetric Information on Market Timing in the Mutual Fund Industry. The International Journal of Managerial Finance, 14 (5). pp. 542-557. ISSN $1743-9132$

It is advisable to refer to the publisher's version if you intend to cite from the work. http://dx.doi.org/10.1108/JJMF-09-2017-0187

For more information about UCLan's research in this area go to http://www.uclan.ac.uk/researchgroups/ and search for <name of research Group>.

For information about Research generally at UCLan please go to http://www.uclan.ac.uk/research/

All outputs in CLoK are protected by Intellectual Property Rights law, including Copyright law. Copyright, IPR and Moral Rights for the works on this site are retained by the individual authors and/or other copyright owners. Terms and conditions for use of this material are defined in the policies page.

\section{CLoK}

Central Lancashire online Knowledge www.clok.uclan.ac.uk

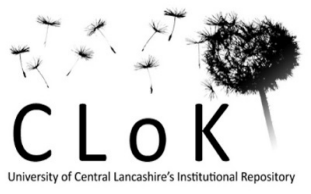




\title{
Effects of asymmetric information on market timing in the mutual fund industry
}

Forthcoming: International Journal of Managerial Finance

\author{
Vanessa S. Tchamyou \\ Faculty of Applied Economics, \\ University of Antwerp, Antwerp Belgium \\ E-mails: simenvanessa@yahoo.com / \\ simenvanessa@afridev.org \\ Simplice A. Asongu \\ Development Finance Centre, \\ Graduate School of Business, \\ University of Cape Town, Cape Town, South Africa. \\ E-mails: asongusimplice@yahoo.com / \\ asongus@afridev.org \\ Jacinta C. Nwachukwu \\ School of Economics, Finance and Accounting, \\ Faculty of Business and Law, \\ Coventry University Priory Street, \\ Coventry, CV1 5FB, UK \\ Email: jacinta.nwachukwu@ coventry.ac.uk
}




\title{
Effects of asymmetric information on market timing in the mutual fund industry \\ Vanessa S. Tchamyou, Simplice A. Asongu \& Jacinta C. Nwachukwu
}

\begin{abstract}
The paper investigates the effects of information asymmetry (between the realised return and the expected return) on market timing in the mutual fund industry. For the purpose, we use a panel of 1488 active open-end mutual funds for the period 2004-2013. We use fund-specific time-dynamic betas. Information asymmetry is measured as the standard deviation of idiosyncratic risk. The dataset is decomposed into five market fundamentals in order to emphasis the policy implications of our findings with respect to (i) equity, (ii) fixed income, (iii) allocation, (iv) alternative and (v) tax preferred mutual funds. The empirical evidence is based on endogeneity-robust Difference and System Generalised Method of Moments. The following findings are established. First, information asymmetry broadly follows the same trend as volatility, with a higher sensitivity to market risk exposure. Second, fund managers tend to raise (cutback) their risk exposure in time of high (low) market liquidity. Third, there is evidence of convergence in equity funds. We may therefore infer that equity funds with lower market risk exposure are catching-up with their counterparts with higher exposure to fluctuation in market conditions. The paper complements the scarce literature on market timing in the mutual fund industry with time-dynamic betas, information asymmetry and an endogeneity-robust empirical approach.
\end{abstract}

Key words: Information asymmetry; Mutual funds; Market timing; Market uncertainty JEL Classification: G12; G14; G18 


\section{Introduction}

The global financial crisis of 2008 had a huge impact on the fund industry due to the collapse of many well established companies in the sector. This financial storm led to changes in investors' habit, by inter alia: (i) reducing their market risk exposure and (ii) confronting them with liquidity risk, systematic risk and other leverage effects (Fabozzi et al., 2010). Accordingly, investors failed to anticipate the global financial meltdown substantially because they were unable to time the market properly ${ }^{1}$ (Tchamyou \& Asongu, 2017). In essence, there are some dynamics like modifications in the disclosure of the underlying asset or differences in investment scenarios, that could not be captured by the timing ability of mutual fund managers (Bodson et al., 2013). It logically follows that the market timing ${ }^{2}$ inability of fund managers prior to the underlying crisis is most traceable to information asymmetry and market uncertainty. Though the fund industry suffered from the 2008 financial crisis, active mutual funds ${ }^{3}$ are becoming increasingly popular. In addition, the United States in which the crisis originated still represents the largest mutual fund market worldwide. As shown in Figure 1, there were $\$ 30$ trillion worth of 7,707 open-end mutual funds with a total net assets of $\$ 15,000$ trillion by the end of the 2013, with the United States and Europe representing 50 percent and 31 percent respectively (ICI, 2014).

\footnotetext{
${ }^{1}$ While scholars in financial engineering have been quick to recognize their inability to predict the recent financial crisis, according to Mitchell (2004, p. 76), future trends in social sciences are supposed to be predicted with almost mathematical precision.

It is important to note that, even if fund managers were able to forecast the crisis, it would have happened anyway because of portfolio composition. In addition, they cannot exit the market and convert their asset into cash.

2 "The concept of "market timing" can potentially be generalized to include the systematic risk factors of the Carhart (1997) and Fama and French (1993) models as well. That is, if a manager could predict how the size (SMB), book-to-market (HML) and momentum (MOM) factors would move, he could purchase stocks with high or low sensitivities to these factors in the exact same way he would for the market"'(Benos et al., 2010, p.509).

${ }^{3}$ A Mutual fund is defined as a company which mobilizes financial resources from different investors for placement in securities like money-market funds, bonds, stocks, or the mix of these investments. It is usually classified into three principal types of investment companies: unit-investment trusts; open-end funds and closed-end funds (SEC, 2008). In this paper, active funds are relative to index and smart beta funds.
} 
Figure 1

Total worldwide mutual fund assets

Percentage of total net assets at the end of the year 2013

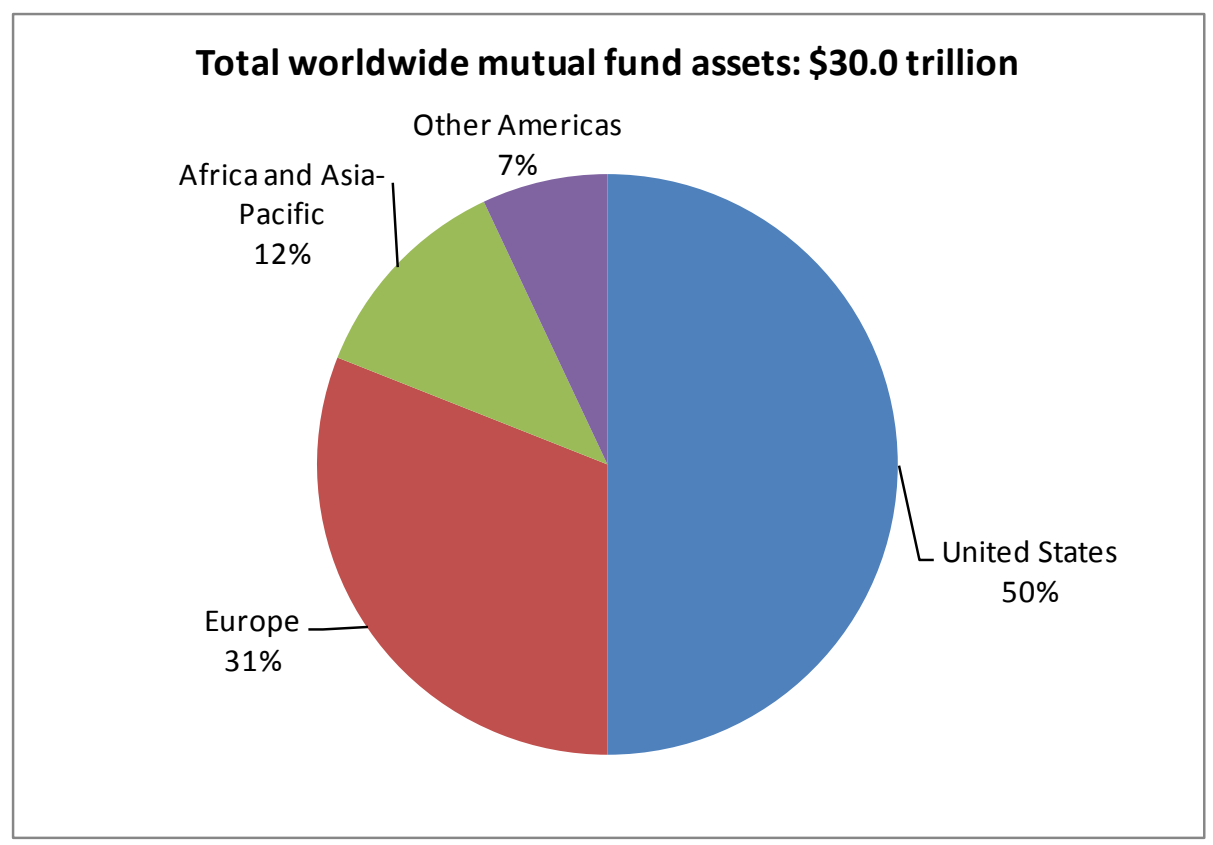

Source: 2014 Investment Company Fact Book

In the light of the above, researchers have had a renewed interest in the market timing ability of active fund managers. We engage the available literature in two main strands: (i) preand (ii) post-2008 financial crisis.

In the first strand, we tackle the literature prior to the 2008 financial crisis which also highlights the theoretical underpinnings of the study. Since the fundamental research of Treynor and Mazuy (1966), studies on the ability of fund managers to time the market have been widely explored. Many authors including Treynor and Mazuy (1966); Kon (1983); Chang and Lewellen (1984); Henriksson (1984); Lee and Rahman (1990); Busse (1999); Bollen and Busse, (2001) and Jiang et al. (2007) worked on the ability of mutual fund managers to employ their predicting capacity of future market returns to obtain abnormal returns. These authors investigated the timing ability of mutual fund managers from different perspectives, notably in market returns, liquidity and volatility. For example, with respect to volatility timing, Busse (1999) used daily mutual fund returns to show that the ability of fund managers to time volatility is a substantial factor in determining returns that could lead to higher risk-adjusted results.

The second stream of the literature embodies more recent studies on the timing ability of mutual fund managers. Clare et al. (2016) employed two different methods - returns-based method and holdings-based approach — to examine whether a multi-asset class is able to time the market. Their results showed little evidence of the ability of fund managers to accurately time 
multi-asset class. Kacperczyk et al. (2014) have suggested a new definition how to persistently time the market with cognitive ability. They proposed a new measure of managers' market timing ability in periods of economic recession. Further, using monthly holding data to examine mutual fund timing ability, Elton et al. (2011) found significantly positive results which show that managers are able to time the market substantially. Frijns et al. (2013) proposed a new approach based on a heterogeneous agent model; a switching rule between cash and stocks; to determine the timing ability of mutual fund managers. Applying that rule to equity mutual funds, they found that only 3.25 percent have positive timing ability whereas 41.5 percent have negative timing skills. Liquidity timing has been assessed by Cao et al. (2013). They recommended that investment managers could adapt their un-diversifiable risk based on the scale of aggregate liquidity. To be sure, fund managers will tend to decrease their market exposure in periods of low liquidity and vice-versa when liquidity increases. Their results indicated that mutual fund managers reduced their exposure to market risk when global liquidity is low, sustaining the position that mutual fund managers have an ability to time market liquidity. In addition, perspectives of market volatility, market return and aggregate liquidity have been investigated in a global context (Bodson et al., 2013, p.96). According to the authors, an average of 6 percent of mutual fund returns involve market timing abilities, while 13 percent of this average accounts for the volatility timing and 14 percent for the liquidity timing of managers.

As far as we have garnered from the above literature, there is room for improvement in at least three main areas, namely: data; methodology and policy relevance. Hence our contribution to the literature is threefold.

First, five sub-contributions are noteworthy from the data perspective: (i) need for an updated sample, (ii) scanty empirical evidence based on panel data structure, (iii) interest of modelling information uncertainty and information asymmetry simultaneously, (iv) use of data with annual periodicity and (v) decomposition of the dataset into market fundamental characteristics to avail room for more policy options for the fund managers. We substantiate on the highlighted contributions in the following ways. (1) Previous studies on market timing have data limited to the year 2010 for the most part (Benos et al. 2010, p.510 ; Bodson et al. 2013, p.97; Cao et al. 2013, p.282; Kacperczyk et al. 2014). By employing a dataset for the period 2004-2013, for which estimation constraints allow for missing observations only in the first-four years, our findings are fundamentally based on an updated sample ${ }^{4}$. (2) Contrary to the bulk of

\footnotetext{
${ }^{4}$ We refer the interested reader to the methodology section for insights into the computation of time-dynamic betas and information asymmetry. Accordingly, the specification constraint is such that the adopted rolling window in the market model should be higher than the number of independent variables by at least one degree of freedom. Since, we
} 
literature that is based on cross-sectional and time series data structures ( $\mathrm{Lu}$ et al., 2010; Dierkens,1991), the use of panel data has the advantage of accounting for cross-fund variations in the market timing modelling exercise. (3) We steer clear of the engaged literature above by simultaneously modelling information uncertainty and information asymmetry, with the former (latter) measured by the stochastic volatility of returns ${ }^{5}$ (the standard deviation of differences between realised return and expected returns estimated with the Fama and French (1992) three factor model ${ }^{6}$ ). (4) The bulk of underlying literature is based on daily and monthly returns (Elton et al., 2011; Cao et al., 2013, p.282 ; Kacperczyk et al., 2014). By using annual or low frequency data, we mitigate short-run or business-cycle disturbances that may loom considerably in the market. It is interesting to note that business cycle disturbances inhibit the convergence of common policy initiatives (Islam, 1995) which may be adopted collectively by some fund managers. (5) The decomposition of our dataset into fundamental characteristics (based on equity, fixed income, allocation, alternative and tax preferred funds) provide ample room for more targeted policy implications to managers concerned with only certain features of the fund industry. This positioning is consistent with Elton et al. (2011) on the view that the available literature is focused on equity funds for the most part (Kacperczyk et al., 2014; Bodson et al., 2013; Benos et al.,2010).

Second, contributions on the methodological front are at least threefold. Accordingly, the adopted empirical strategies: (i) accommodate the persistent nature of returns and corresponding betas, (ii) account for cross-fund variations and endogeneity and (iii) compute time-dynamic information uncertainty, information asymmetry and fund-specific betas. For brevity, these empirical approaches which broadly steer clear of those adopted in the discussed literature are substantially engaged in the methodology section.

Third, the policy relevance is at least threefold. (1) Essence of convergence or catch-up in market exposure among funds. Accordingly, evidence of catch-up theoretically implies the feasibility of common policy initiative among funds within a specific category or homogenous panel. (2) Policy implications from fundamental characteristics are relevant because market timing studies in the mutual fund industry have been based on equity funds for the most part. There are growing calls for more complete studies that go beyond equity funds in the assessment of mutual fund managers' market timing abilities (Elton et al., 2011). (3) The distinction between the effects of information asymmetry (hereafter IA) and uncertainty in market timing has crucial

have four independent variables for the market model, the time window is set to five, hence providing time-dynamic betas with missing observations in the first-four years of every fund.

${ }^{5}$ Using the first-order autoregressive processes of underlying returns

${ }^{6}$ Here after FF 3 factor model. 
policy relevance because these two concepts have been used interchangeably in prior expositions. From a preliminary assessment based on correlation analysis, these two concepts do not appear to display a high degree of substitution warranting concerns of over-parameterization.

In the light of the above, we complement existing literature by positioning the present line of inquiry on the information asymmetry effects on market timing in the mutual fund industry. Hence we devote space to (i) discussing the intuition of and theoretical underpinnings for the study and (ii) clarifying the context of information asymmetry which is a complex and multifaceted concept.

We estimate the effects of information asymmetry between fund managers and the market in the mutual fund industry. Corresponding differences between the realised return (provided by the market) and the expected return (by the fund manager) can be a source of information mismatched which sometimes may mitigate the timing ability of mutual fund managers. Asymmetry in information also refers to the lack of knowledge of the market by fund managers or investors. Additionally, it shows that some managers have more knowledge about the firm value because private information is at their disposal prior to the market (Dierkens, 1991, p.183). It also refers to a situation where market players have different sets of information (Lu et al., 2010).

Consistent with our motivation and theoretical foundation, information asymmetry will determine the choice of investment portfolios and strategies. Moreover, market exposure should be an increasing function of market knowledge. Following Dai et al. (2013), Dierkens (1991) and Ivashina (2009), we use the standard deviation of idiosyncratic risk of investors' return as an instrument of information asymmetry.

The rest of the paper proceeds as follows. Section 2 describes our dataset and discusses the methodology. We tackle the empirical analysis, presentation of results and related policy implications in Section 3. Section 4 concludes.

\section{Data and Methodology}

\subsection{Data}

Information on mutual fund data is sourced from Morningstar Direct for the period 2004-2013. We have selected open-end mutual funds investing in domestic funds and we use the Global Broad Category Group from the underlying source. The classification is made of 243 fixed income funds, 882 equity funds, 156 allocation funds, 15 alternative funds and 186 tax-preferred funds. We process the data to remove missing observations and ensure a strongly balanced panel data structure made-up of 1488 mutual funds, with 10 annual observations. 


\subsection{Methodology}

\subsubsection{Estimation of volatility, beta and information asymmetry}

There are different measures of information asymmetry in the existing literature, depending on the study. Dierkens (1991) used four proxies to measure asymmetry of information between firm managers and the market in the context of equity issues. Ivashina (2009) assessed the cost resulting from irregularity in information between elements of a lending syndicate and the lead bank. Consistent with the same definition, Dai et al. (2013) employed the standard deviation of idiosyncratic risks of return in assessing how information unevenness and mutual fund ownership influenced the earnings management of listed companies. A common denominator among these studies is that asymmetric information is the difference between realised and expected returns. Hence, in this study, information asymmetry is computed using the standard deviation of the idiosyncratic risk of returns ${ }^{7}$. Idiosyncratic information asymmetry refers to the standard deviation of the residuals of individual returns. Within the context of this study, while we use the Capital Asset Pricing Model (CAPM) augmented with the FF three factor model (see Eq.2 below), a stochastic modelling approach is employed to obtain the variable used as proxy for information uncertainty or volatility.

Volatility of returns is computed as standard errors from first order auto-regressive processes of the returns. Borrowing from Kangoye (2013) and Asongu et al. (2017), on the computation of uncertainties or volatilities, auto-regressive models are used for low frequency data. Hence, we apply this methodology since our dataset is made of annual open-end mutual funds. The saved RMSE $^{8}$ (Root-Mean_Square Error) of each return obtained from the first autoregressive processes are used as uncertainty (or volatility). The computation process is summarised in the following equation.

$$
R_{i, t}=\alpha+\varphi R_{i, t-1}+\kappa T+\varepsilon_{i, t}
$$

Where $R_{i, t}$ is the return of fund $i$ at time $t ; R_{i, t-1}$ the return of fund $i$ at time $t-1 ; T$ the time trend; $\alpha$ the constant ; $\varphi$ is the parameter of interest to be estimated and $\varepsilon_{i, t}$ the error term.

\footnotetext{
${ }^{7}$ The idiosyncratic risk of return is the same as abnormal returns. That is the difference between the realized return and the expected one.

${ }^{8}$ The RMSE (Root-Mean-Square Error) can be used as the standard deviation of residuals or as a measure of uncertainty (Kitagawa \& Okuda, 2013).
} 
We model mutual fund expected returns with the FF three-factor model to estimate fund-specific systematic risk.

$$
R_{i, t}-R_{f, t}=\alpha_{i}+\beta_{M K T, i, t} M K T_{t}+\beta_{S M B, i} S M B_{t}+\beta_{H M L, i} H M L_{t}+\varepsilon_{i, t}
$$

Where $R_{f}$ is the risk free rate, $M K T$ is the market excess return, $S M B$ Small [market capitalization] Minus Big [market capitalization] and $H M L$ High [book-to-market ratio] Minus Low [book-to-market ratio]. The aforementioned three factors are taken from the Kenneth French's website ${ }^{9}$.

A simple view of information asymmetry can then be modelled as follows:

$$
I A_{i, t}=\sigma\left(R_{i, t}-\hat{R_{i, t}}\right)
$$

Where $I A$ is Information Asymmetry; $\sigma$ the standard deviation; $R_{i, t}$ the realised return of fund $i$ at time $t ; \hat{R_{i, t}}$ is the expected return computed using the FF three factor model. We estimate time dynamic betas corresponding to each fund as a measure of market timing or exposure. The advantage of having a time varying beta is that it captures more realistic changes in market conditions since we have a different beta for each return and each year. Such is in line with the wealth of literature cautioning that the beta of an asset may not be fixed over time (Ferson \& Schadt, 1996, p.428). The time-dynamic betas and RMSE for information asymmetry are estimated from Equation 2 using the Rollreg Stata command. Given that the time-window must be higher than the number of independent variables by at least one degree of freedom, we adopt a five year moving-window such that we have only four missing observations for each fund.

To estimate the liquidity ${ }^{10}$ risk measure, we use the aggregate liquidity factors of the updated series of Pástor and Stambaugh (2003). All factors are retrieved from Robert Stambaugh's Website $^{11}$ (See Bodson et al., 2013). Since we have annual mutual fund data and the liquidity measures are in months, we compute annual averages using the monthly data. Appendix 1 presents the definition of variables.

Please insert Table 1 here.

\footnotetext{
${ }^{9}$ Kenneth French's website: http://mba.tuck.dartmouth.edu/pages/faculty/ken.french/data library.html 10 "Aggregate liquidity" and "liquidity" are used interchangeably in the study.

${ }^{11}$ Robert Stambaugh's Website: http://finance.wharton.upenn.edu/ stambaugh/
} 
Table 1 presents the summary statistics for mutual fund categories and variables in Panel A and Panel B respectively. There is, at least, a twofold motivation for the disclosure. On the one hand, we observe from the mean values that the variables are comparable. On the other, it shows from the standard deviations that there is a substantial variability in the indicators. Therefore, some statically significant relationships could be expected.

The correlation matrix presented in Table 2 below has two main objectives. It allows us to mitigate errors arising from over-parameterization and multicollinearity between variables which are simultaneously employed in the same model. In this regard 'market excess return' and 'aggregate liquidity' are not specified in the same model, since their correlation coefficient is 0.7498. The inference is that, approximately 74 percent of the aggregate liquidity risk can be explained by market excess return. In other words a high scale of market liquidity can be linked with a high measure of market return (Cao et al., 2013, p.285).

Consistent with the literature (Bodson et al., 2013), we have specified size and book-tomarket ratio in the same model for the estimation of the beta (market timing) despite their high level of correlation.

Please insert Table 2 here.

\subsubsection{Model}

The methodologies adopted in this paper are the difference and the system GMM (Generalized Method of Moments). There are at least six main reasons for adopting this empirical strategy. They are (i) cross-fund variation; (ii) persistence of betas; (iii) endogeneity; (iv) noncontemporaneous specifications, (v) variation of variables and (vi) consistency with the data structure.

First, contrary to time series specifications, the dynamic panel estimation technique corrects for cross-fund variations in the determination of estimated coefficients. Hence, both time series and cross-sectional variations are accounted for.

Second, return in the fund industry and corresponding betas have been documented to be persistent (Carhart, 1997) and a fundamental condition for the employment of the GMM estimation strategy is persistence in the dependent variable. Moreover, the auto-regressive processes used in the computation of information uncertainty are based on the assumption of persistence of the return variables. 
Third, given that betas in the fund industry are endogeneous (Blocher, 2013) the adopted estimation strategy controls for time invariant omitted variables (or unobserved heterogeneity) and simultaneity bias through the use of instrumental variables.

Fourth, non-contemporaneous specifications make more economic sense than contemporaneous regressions in the fund industry (Blocher, 2014). The instrumentation process in the system GMM specification involves non-contemporary effects of the independent variables on the outcome indicator.

Fifth, consistent with Bodson et al. (2013, p.98), the modelling of market timing is tailored to capture changes in the variables. Hence, by taking changes (or deviations) into account, the GMM specifications are consistent with modelling of the market timing ability of mutual funds managers.

Sixth, the empirical strategy is consistent with data structure $(\mathrm{N}>\mathrm{T}) \Rightarrow \mathrm{N}=1488$ and $\mathrm{T}=$ 10. In essence, the GMM estimation technique is a good-fit for data structures in which $\mathrm{N}$ (numbers of individuals/cross-sections) is large and T (time series/periods) is small (Arellano \& Bond, 1991).

The estimation technique is presented as follows, with Eq. (3) and Eq. (4) in level and first difference respectively.

$$
\begin{aligned}
& \beta_{i, t}=\alpha_{0, t}+\alpha_{1, t} \beta_{i, t-1}+\alpha_{2, t} M K T_{i, t}+\alpha_{3, t} I A_{i, t}+\alpha_{4, t} \operatorname{Vol}_{i, t}+\alpha_{5, t} \operatorname{Liq}_{i, t}+\eta_{i}+\xi_{t}+\varepsilon_{i, t} \\
& \beta_{i, t}-\beta_{i, t-1}=\alpha_{1, t}\left(\beta_{i, t-1}-\beta_{i, t-2}\right)+\alpha_{2, t}\left(M K T_{i, t}-M K T_{i, t-1}\right)+\alpha_{3, t}\left(I A_{i, t}-I A_{i, t-1}\right)+ \\
& \alpha_{4, t}\left(\operatorname{Vol}_{i, t}-\operatorname{Vol}_{i, t-1}\right)+\alpha_{5, t}\left(L i q_{i, t}-L i q_{i, t-1}\right)+\left(\xi_{t}-\xi_{t-1}\right)+\left(\varepsilon_{i, t}-\varepsilon_{i, t-1}\right)
\end{aligned}
$$

where, $\beta_{i, t}$ is the beta of fund $i$ at period $t ; \alpha$ is a constant; MKT, Market excess return ; IA, Information Asymmetry; $\mathrm{Vol}$, Volatility, Liq , Liquidity, $\eta_{i}$ is the country (or fund) -specific effect, $\xi_{t}$ is the time-specific constant and $\varepsilon_{i, t}$ the error term. To control for heteroscedasticity, the two-step procedure has been preferred to the one-step procedure in the specification.

While the difference GMM approach is based on Eq. (5), the system GMM adds the level equation to Eq. (5). Whereas the instrumentation procedure in the difference GMM entails the use of lagged levels of the regressors as instruments, the process in the system GMM requires lagged differences of the regressors as instruments in the level equation and lagged levels of the regressors as instruments in the difference equation. This non-contemporanoeus dimension also 
enables the exploitation of all orthogonality conditions between the lagged endogeneous variable and the error term.

\section{Empirical Analysis and Discussion of Results}

\subsection{Presentation of Results}

Table 3 and Table 4 present the results of the regression analysis. Table 3 discloses the findings of the difference GMM while Table 4 reveals the results for the system GMM. In the specifications, not all independent variables are modelled together to avoid issues of overparameterization and multicollinearity already discussed above. The first two specifications represent the baseline model while the remaining models are for each of our five categories of mutual funds: equity; fixed income; allocation; alternatives and tax-preferred funds. This enables us to assess if the reaction of a mutual fund manager in timing the market is sensitive to fund type. All specifications are robust to heteroscedasticity because we have adopted a two-step procedure. Time fixed effects are also taken into account in all specifications.

Most of the variables have the expected signs. (1) Information asymmetry is significantly negative in the baseline model (Table 4), equity funds (Table 4), fixed income funds (Table 3 and Table 4) and allocation funds (Table 4). Unexpected positive signs are found in tax-preferred funds. (2) Volatility is significantly negative except for the allocation funds. (3) Aggregate liquidity is expectedly positive and statistically significant for all our fund types, with the exception of allocation funds. (4) Market excess return in the baseline model (first specification) is not significant. But in the regression for fixed income and alternative funds, we find positive significant results contrary to the significantly negative association estimated for the equity mutual fund.

The validity of the models based on the information criteria is appealing for the most part. Accordingly, the Wald Chi-square for the overall validity of models is overwhelmingly significant at a 1 percent level. Additionally, following a rule of thumb, the number of instruments is generally lower than the number of cross-sections. This implies that most of our results do not really suffer from instrument proliferation or over-identification (difference between instruments and endogeneous explanatory variables).

Please insert Table 3 and Table 4 here.

\subsection{Further Discussion of Results and Policy Implications}


In this sub-section, we discuss the results with related policies in three main areas. First, we report the global relevance of our baseline specifications in Table 3 and Table 4 for difference and system GMM estimations respectively. Second, we further explain the meaning and implication of our findings by fund categories and finally, we emphasise the consequences for convergence.

\subsubsection{Global results}

Policy implications are deduced based on the results in Table 3 and Table 4. More specifically, we focus on those recommendations which could be adapted by managers to suit the investment profile of each fund category.

Results in the first two columns of the baseline model in Table 3 and Table 4 show that most of the variables have the expected signs. First, the significant negative outcomes in Table 4 are predictable given that asymmetry in information in this study is measured as the difference between realised and expected returns ${ }^{12}$. Thus, its expected sign should intuitively be the same as that of volatility. Second, the negative sensitivity of the volatility timing ability of fund manager is consistent with the empirical underpinnings on the association between high levels of volatility and systematic risk (Bodson et al., 2013; Cao et al., 2013; Busse, 1999). Third, liquidity timing is positive and significant. This means that managers of funds accurately predict high (low) liquidity market and therefore increase (or decrease) their exposure to the market (Cao et al. 2013). Fourth, generally speaking, the findings in Column 1 of Table 3 and Table 4 indicate that fund managers do not have substantial return timing ability. This is essentially because the effect of excess market return is not consistently significant. Accordingly, excess market return should increase market exposure. This conclusion is consistent with Bodson et al. (2013).

So far, we have exclusively reported the signs of the independent variables of interest. But for more subtlety in the policy implications it is also worthwhile to comparatively discuss the magnitude of estimated coefficients which can also be understood as the 'degree of responsiveness of fund managers' to market exposure. Broadly speaking, for both Table 3 and Table 4, two practical implications are apparent: First, the negative sensitivity of volatility is higher than that of information asymmetry ${ }^{13}$. This finding is in line with those of (Busse, 1999) who remarked that negative volatility may lead to risk adjusted competitiveness. As far as we are

\footnotetext{
${ }^{12}$ It is important to note that, if the information asymmetry were between managers and investors, we would have expected opposite or positive signs because increasing positive information asymmetry between them is more likely to increase the earnings management of fund managers. Conversely, higher information asymmetry between fund managers and the market within the context of this study implies fund managers are likely to predict future market returns, hence a potentially decreasing earnings management. This intuition is consistent with Dai et al. (2013, p.197), who have shown that when information asymmetry between investors and fund managers is low, earnings management deteriorates.

13 This comparison does not take variable relativity into account.
} 
aware, there is no comparable literature on information asymmetry in mutual fund industry with which to compare the findings. Additionally, in the context of this work, volatility and information asymmetry are following the same trend. Hence, they may have the same economic interpretation. Second the positive effect of aggregate liquidity is higher compared with the negative impact of volatility and information asymmetry ${ }^{14}$. The higher positive response of liquidity is an indication that managers may have capabilities to forecast performance of mutual funds accurately. Moreover, after verifying the effect of volatility, liquidity is an important factor in the market timing strategy of fund managers (Cao et al., 2013).

\subsubsection{Results per fund category}

For the specifications based on different fund categories, results are generally in accordance with the global findings, but with some notable exceptions. In Table 3, information asymmetry has significant positive effect on the tax preferred funds and negative impact on the fixed income funds. In Table 4, results are almost the same as in Table 3, but with significant negative outcomes for the baseline models and equity funds. No significant results for the alternative mutual funds.

Predictably, volatility has a negative sign in both the baseline model and for each of our selected mutual funds in Table 3 and Table 4. The inference is that fund would tend to reduce their risk exposure in periods when an increase in market volatility is predictable. No significant results are found for tax preferred mutual funds in Table 3 and Table 4; and fixed income funds in Table 4. However, we found positive and significant signs for allocation funds in both tables, meaning that the manager will be substantially exposed to risk. We found the same trend of results for market excess return in the two tables: significantly negative results for equity funds and no substantial outcome for the other fund types. As seen above, this may reflect that fact that managers of mutual funds do not seem to have the ability to forecast their returns with reasonable accuracy. However, significant positive results for fixed income and alternative funds were found in both tables.

\footnotetext{
${ }^{14}$ Whereas the effect of information asymmetry is not significantly negative in Table 3, the System GMM results take precedence over the Difference estimators because the former estimation technique has been documented to be more efficient (Bond et al., 2001). "We also demonstrate that more plausible results can be achieved using a system GMM estimator suggested by Arellano and Bover (1995) and Blundell and Bond (1998). The system estimator exploits an assumption about the initial conditions to obtain moment conditions that remain informative even for persistent series, and it has been shown to perform well in simulations. The necessary restrictions on the initial conditions are potentially consistent with standard growth frameworks, and appear to be both valid and highly informative in our empirical application. Hence we recommend this system GMM estimator for consideration in subsequent empirical growth research". (pp. 3-4)
} 
On the liquidity timing aspect, we found significant positive results for equity and fixed income funds in both tables. These results are consistent with baseline specifications and in accordance with the empirical underpinnings. Allocation funds are reacting differently from what we have expected in terms of liquidity timing. In fact, we find negative significant signs. There is no evidence of liquidity timing in allocation and tax-preferred funds in both tables.

\subsubsection{Convergence and catch-up in market exposure}

In this section, we briefly summarise the significance and economic relevance of the estimated coefficients on our lagged endogenous variable. Consistent with the underlying literature (Islam, 2003), alpha convergence is a reduction of differences in market exposure from a cross-sectional perspective whereas beta convergence is diminishing cross-fund dispersions from a panel stand point. Accordingly, the term catch-up has been employed in mainstream literature to describe beta convergence because of initial endowments and multiple equilibria issues associated with its modelling. Hence, we shall employ the term 'catch-up' for consistency. Moreover, it is interesting to note that 'beta catch-up' by definition is not 'fund beta catch-up'. It is just a double coincidence that the dependent variable employed in this study is termed in 'financial jargon' the same as the concept of catch-up in 'economic jargon'. Hence, for simplicity we employ 'catch-up' interchangeably for 'beta catch-up' and 'fund beta catch-up'.

The version of beta catch-up employed is the conditional catch-up, as opposed to the absolute catch-up version which is not contingent on some conditioning information set or explaining variables. The conditional version is more relevant to this study because catch-up in fund market exposure is contingent on the underlying determinants, notably: information asymmetry, volatility, market excess return and liquidity. Hence, for conditional catch-up to occur there should theoretically be cross-fund differences in the determinants of fund market exposure. In other words, difference should exist among funds in the underlying explaining variables.

Catch-up in fund market exposure implies that funds with lower exposure are catching-up with their counterparts with higher exposure. In other words, the marginal productivity effects of some (or all) of the underlying determinants are higher for funds with initially lower levels of exposure. This interpretation is consistent with the narrative on the higher marginal capital productivity of per capita income in the mainstream convergence literature (Barro \& Sala-iMartin, 1992) ${ }^{15}$. From a contextual perspective, the catch-up process means that the Left Hand

\footnotetext{
${ }^{15}$ Developing countries will grow at faster rate than advanced nations because of higher marginal productivity of capital. Hence, the development catch-up process.
} 
Side of Eq. (5) is decreasing over time because past differences have a less proportional effect on future differences.

Evidence of catch-up is established from our findings if (i) the estimated coefficient on the lagged endogenous variable is statistically significant at the five percent level and (ii) its corresponding absolute value is between 0 and 1 . From our findings, this information criterion holds only for baseline and equity fund results.

Four main implications can be established. First, from a broad perspective, funds with lower market exposure are catching-up their counterparts with higher market exposure. Second, when the dataset is disaggregated into fund-specific categories this catch-up pattern is only apparent for equity funds. This evidence is supported by the fact that, of the 1488 sampled funds in the industry there are 882 equity funds. It should be noted that the absence of convergence in other funds does not imply divergence because an information criterion for such a conclusion (or equation) to the best of our knowledge has not yet been properly worked-out in the literature. Third, a practical implication for catch-up in market exposure among funds managers in the industry is the feasibility of common policy initiatives that can be applied without distinction of funds' localities and/or nationalities from which underlying fund managers operate. Such feasibility in policy harmonization is particularly relevant in mitigating or averting far-reaching negative tendencies in fund management that may have very negative implications like the global financial crisis. Fourth, catch-up in the fund industry has financial relevance because theoretically, in the presence of full catch-up, the possibility of supernormal profits among fund managers disappear, such that fund managers with the same levels of information asymmetry and volatility forecast have the same levels of returns from the common market.

\section{Conclusion}

In this paper we have investigated the effects of information asymmetry on market timing in the mutual fund industry. The empirical analysis is based on different fund categories: equity funds; fixed income funds; allocation funds; alternative funds and tax preferred funds. The following findings have been established. First, information asymmetry broadly follows the same trend as volatility, meaning that while fund managers reduce their risk exposure to the underlying factors, their responsiveness to volatility is higher relative to information asymmetry. Second, with respect to liquidity, fund managers tend to raise (cutback) their risk exposure in time of high (low) market liquidity. Third, we also find evidence of convergence in equity funds, implying that equity funds with lower market exposure are catching-up their counterparts with higher market exposure. 
Understanding the timeline for the catch-up process could provide the basis for common policies among fund managers in the industry. While we have resisted the temptation of involving this dimension because it is out of the scope of the present study, it remains an interesting future line of inquiry. Other further research directions may comprise, inter alia (i) assessing the investigated factors throughout the conditional distributions of market exposure to address the potential downsides of blanket policies based on estimated strategies that are focused on mean values of market exposure and (ii) examining thresholds for which the sensitivity of fund managers' market timing abilities are based. 
Table 1

Summary statistics

This table presents the summary statistics of fund categories (Panel A) and variables used in our analysis (Panel B).

\begin{tabular}{|c|c|c|c|c|c|}
\hline \multicolumn{6}{|c|}{ Panel A: Mutual fund categories } \\
\hline Variables & Mean & Std. Dev. & Min & Max & Obs. \\
\hline Equity & 0.5927419 & 0.4913402 & 0 & 1 & 14880 \\
\hline Fixed Income & 0.1633065 & 0.3696575 & 0 & 1 & 14880 \\
\hline Allocation & 0.1048387 & 0.3063558 & 0 & 1 & 14880 \\
\hline Alternative & 0.0100806 & 0.0998984 & 0 & 1 & 14880 \\
\hline Tax Preferred & 0.125 & 0.33073 & 0 & 1 & 14880 \\
\hline \multicolumn{6}{|l|}{ Panel B: Variables } \\
\hline Beta & -0.018 & 0.932 & -4.502 & 4.571 & 8928 \\
\hline Info. Asymmetry & 19.467 & 15.245 & 0.000 & 93.425 & 8928 \\
\hline Volatility & 25.980 & 12.115 & 0.691 & 64.902 & 7440 \\
\hline Mkt Excess Return & 8.578 & 19.038 & -38.39 & 35.15 & 14880 \\
\hline SMB & 3.003 & 7.485 & -7.01 & 17.74 & 14880 \\
\hline HML & 2.411 & 12.342 & -21.55 & 23.66 & 14880 \\
\hline Aggregate Liquidity & -0.025 & 0.028 & -0.098 & 0.010 & 14880 \\
\hline
\end{tabular}

SMB: Size. HML: Book to market. Std. Dev.: Standard Deviation. Min.: Minimum. Max. : Maximum. Obs.: Observations.

Table 2

Correlation matrix

This table presents the correlation matrix of variables used in our analysis

\begin{tabular}{|c|c|c|c|c|c|c|c|}
\hline $\begin{array}{l}\text { Info. } \\
\text { Asymmetry }\end{array}$ & Volatility & $\begin{array}{l}\text { Mkt Excess } \\
\text { Return }\end{array}$ & SMB & HML & $\begin{array}{l}\text { Aggregate } \\
\text { Liquidity }\end{array}$ & Beta & \\
\hline \multirow[t]{7}{*}{1.0000} & 0.1868 & -0.0125 & -0.0413 & -0.0307 & 0.0137 & 0.0186 & Info. Asymmetry \\
\hline & 1.0000 & -0.0418 & -0.0308 & -0.0090 & 0.0337 & 0.0050 & Volatility \\
\hline & & 1.0000 & 0.5516 & 0.5184 & 0.7498 & 0.0231 & Mkt Excess Return \\
\hline & & & 1.0000 & 0.7186 & 0.0298 & -0.0201 & SMB \\
\hline & & & & 1.0000 & 0.2964 & 0.0123 & HML \\
\hline & & & & & 1.0000 & 0.0512 & Aggregate Liquidity \\
\hline & & & & & & 1.0000 & Beta \\
\hline
\end{tabular}


Table 3

Regression Analysis

This table presents the regression analysis for the Difference GMM

Difference GMM (xtabond) (Dependent variable: Beta)

\begin{tabular}{|c|c|c|c|c|c|c|c|c|c|c|c|c|}
\hline \multirow[b]{2}{*}{ Constant } & \multicolumn{2}{|c|}{ Baseline } & \multicolumn{2}{|c|}{ Equity } & \multicolumn{2}{|c|}{ Fixed Income } & \multicolumn{2}{|c|}{ Allocation } & \multicolumn{2}{|c|}{ Alternative } & \multicolumn{2}{|c|}{ Tax Preferred } \\
\hline & $\begin{array}{l}\mathbf{0 . 1 4 6 * *} \\
(0.037)\end{array}$ & $\mathbf{0 . 1 7 6}^{* * *}$ & $\begin{array}{l}\mathbf{0 . 2 3 3}^{*} \\
(0.015)\end{array}$ & 0.264**** & $\begin{array}{l}-0.171 \\
(0.170)\end{array}$ & $\begin{array}{l}0.139 \\
(0298)\end{array}$ & $\begin{array}{l}-0.301 \\
(0.65)\end{array}$ & $\begin{array}{c}-\mathbf{0 . 3 3 5} \\
(0.664)\end{array}$ & 0.250 & 0.539* & $\begin{array}{l}-0.264 \\
(0.168)\end{array}$ & $\begin{array}{l}-0.188 \\
(0.452)\end{array}$ \\
\hline Beta(-1) & $\begin{array}{l}-\mathbf{0 . 5 3 5} * * * * \\
(0.000)\end{array}$ & $\begin{array}{l}-\mathbf{0 . 5 5 7} * * * * \\
(0.000)\end{array}$ & $\begin{array}{l}-\mathbf{- 0 . 2 7 9} * * * \\
(0.007)\end{array}$ & $\begin{array}{l}-\mathbf{0 . 3 3 7} * * * * \\
(0.002)\end{array}$ & $\begin{array}{l}-1.062 \text { \%*** } \\
(0.000)\end{array}$ & $\begin{array}{l}-1.264 * * * * \\
(0.000)\end{array}$ & $\begin{array}{l}0.176 \\
(0.310)\end{array}$ & $\begin{array}{l}0.154 \\
(0.336)\end{array}$ & $\begin{array}{l}-0.166 \\
(0.822)\end{array}$ & $\begin{array}{l}-0.214 \\
(0.695)\end{array}$ & $\begin{array}{l}-\mathbf{3 . 1 5 4} * * * * \\
(0.000)\end{array}$ & $\begin{array}{l}-\mathbf{3 . 1 7 3}^{* * * *} \\
(0.000)\end{array}$ \\
\hline Info. Asymmetry & $\begin{array}{l}-0.000 \\
(0.539)\end{array}$ & $\begin{array}{l}-0.001 \\
(0.155)\end{array}$ & $\begin{array}{l}-0.000 \\
(0.950)\end{array}$ & $\begin{array}{l}-0.000 \\
(0.776)\end{array}$ & $\begin{array}{l}-\mathbf{- 0 . 0 0 5 *} \\
(0.015)\end{array}$ & $\begin{array}{l}\mathbf{- 0 . 0 0 7 * * * *} \\
(0.001)\end{array}$ & $\begin{array}{l}-0.002 \\
(0229)\end{array}$ & $\begin{array}{l}-0.003 \\
(0.198)\end{array}$ & $\begin{array}{l}-0.001 \\
(0.884)\end{array}$ & $\begin{array}{l}-0.004 \\
(0.635)\end{array}$ & $\begin{array}{l}\mathbf{0 . 0 1 6 * * * *} \\
(0.000)\end{array}$ & $\begin{array}{l}\text { 0.015**** } \\
(0.000)\end{array}$ \\
\hline Volatility & $\begin{array}{l}-\mathbf{0 . 0 0 5 *} \\
(0.056)\end{array}$ & $\begin{array}{l}-\mathbf{0 . 0 0 5 *} \\
(0.053)\end{array}$ & $\begin{array}{l}-\mathbf{0 . 0 0 7 * * *} \\
(0.042)\end{array}$ & $\begin{array}{l}-\mathbf{- 0 . 0 0 6 * *} \\
(0.038)\end{array}$ & $\begin{array}{l}-0.004 \\
(0.278)\end{array}$ & $\begin{array}{l}-\mathbf{- 0 . 0 0 9 *} \\
(0.036)\end{array}$ & $\begin{array}{l}\text { 0.016**** } \\
(0.009)\end{array}$ & $\begin{array}{l}\text { 0.017*** } \\
(0.011)\end{array}$ & $\begin{array}{l}-\mathbf{- 0 . 0 3 9} * * \\
(0.022)\end{array}$ & $\begin{array}{l}-\mathbf{- 0 . 0 3 3} * * \\
(0.033)\end{array}$ & $\begin{array}{l}-0.000 \\
(0.901)\end{array}$ & $\begin{array}{l}-0.003 \\
(0.562)\end{array}$ \\
\hline Mkt Excess Return & $\begin{array}{l}0.000 \\
(0.396)\end{array}$ & -- & $\begin{array}{l}-\mathbf{- 0 . 0 0 3 * * *} \\
(0.032)\end{array}$ & --- & $\begin{array}{l}\text { 0.012**** } \\
(0.000)\end{array}$ & -- & $\begin{array}{l}0.001 \\
(0.526)\end{array}$ & -- & $\begin{array}{l}\text { 0.019* } \\
(0.076)\end{array}$ & --- & $\begin{array}{l}-0.002 \\
(0.210)\end{array}$ & -- \\
\hline Aggregate Liquidity & -- & $\begin{array}{l}\text { 3.111**** } \\
(0.000)\end{array}$ & --- & $\begin{array}{l}\text { 7.894**** } \\
(0.000)\end{array}$ & --- & $\begin{array}{l}2.872 \\
(0.109)\end{array}$ & -- & $\begin{array}{l}-\mathbf{- 6 . 7 0 6 * * * *} \\
(0.005)\end{array}$ & -- & $\begin{array}{l}-3.558 \\
(0.329)\end{array}$ & --- & $\begin{array}{l}2.325 \\
(0.307)\end{array}$ \\
\hline Information criteria & & & & & & & & & & & & \\
\hline Numbers of Obs. & 5952 & 5952 & 3528 & 3528 & 972 & 972 & 624 & 624 & 60 & 60 & 744 & 744 \\
\hline Num. of Cross-sec. & 1488 & 1488 & 882 & 882 & 243 & 243 & 156 & 156 & 15 & 15 & 186 & 186 \\
\hline Numbers of Ins. & 14 & 14 & 14 & 14 & 14 & 14 & 14 & 14 & 14 & 14 & 14 & 14 \\
\hline Wald Chi2 & $\begin{array}{l}\mathbf{3 9 . 2 0}^{* * * *} \\
(0.000)\end{array}$ & $\begin{array}{l}\mathbf{4 9 . 6 3}^{* * * *} \\
(0.000)\end{array}$ & $\begin{array}{l}\mathbf{1 2 . 3 8}^{* * *} \\
(0.014)\end{array}$ & $\begin{array}{l}\mathbf{5 4 . 6 5}^{* * * *} \\
(0.000)\end{array}$ & $\begin{array}{l}\mathbf{6 0 . 7 1}^{* * * * *} \\
(0.000)\end{array}$ & $\begin{array}{l}\mathbf{3 7 . 7 1}^{* * * *} \\
(0.000)\end{array}$ & $\begin{array}{l}\mathbf{9 . 0 1 *} \\
(0.060)\end{array}$ & $\begin{array}{l}\text { 11.51** } \\
(0.021)\end{array}$ & $\begin{array}{l}7.31 \\
(0.120)\end{array}$ & $\begin{array}{l}\text { 13.44**** } \\
(0.009)\end{array}$ & $\begin{array}{l}\mathbf{2 2 2 . 1 6}^{* * * *} \\
(0.000)\end{array}$ & $\begin{array}{l}\text { 224.71**** } \\
(0.000)\end{array}$ \\
\hline
\end{tabular}

P-values are in brackets. ***,***: significance levels of $10 \%, 5 \%$ and $1 \%$ respectively. Numbers of Obs.: Numbers of observations. Num. of Cross-sec.: Numbers of Cross-sections. Numbers of Ins.: Numbers of Instruments. 
Table 4

Regression Analysis

This table presents the regression analysis for the System GMM

System GMM (xtdpdsys) (Dependent variable: Beta)

\begin{tabular}{|c|c|c|c|c|c|c|c|c|c|c|c|c|}
\hline \multirow[b]{2}{*}{ Constant } & \multicolumn{2}{|c|}{ Baseline } & \multicolumn{2}{|c|}{ Equity } & \multicolumn{2}{|c|}{ Fixed Income } & \multicolumn{2}{|c|}{ Allocation } & \multicolumn{2}{|c|}{ Alternative } & \multicolumn{2}{|c|}{ Tax Preferred } \\
\hline & $\begin{array}{l}\mathbf{0 . 3 0 7} \text { **** } \\
(0.000)\end{array}$ & $\begin{array}{l}\mathbf{0 . 2 6 4} * * * * \\
(0.000)\end{array}$ & $\begin{array}{l}\mathbf{0 . 4 9 0} \text { **** } \\
(0.000)\end{array}$ & $\begin{array}{l}\mathbf{0 . 3 8 4} * * * * \\
(0.000)\end{array}$ & $\begin{array}{l}-0.182 \\
(0.230)\end{array}$ & $\begin{array}{l}0.000 \\
(0.997)\end{array}$ & $\begin{array}{l}-0.251 \\
(0.194)\end{array}$ & $\begin{array}{l}\mathbf{- 0 . 3 1 3 *} \\
(0.061)\end{array}$ & $\begin{array}{l}0.160 \\
(0.630)\end{array}$ & $\begin{array}{l}0.468 \\
(0.324)\end{array}$ & $\begin{array}{l}-0.200 \\
(0.302)\end{array}$ & $\begin{array}{l}-0.359 \\
(0.103)\end{array}$ \\
\hline Beta $(-1)$ & $\begin{array}{l}-\mathbf{0 . 6 8 3} * * * * \\
(0.000)\end{array}$ & $\begin{array}{l}-\mathbf{0 . 6 8 1} * * * * \\
(0.000)\end{array}$ & $\begin{array}{l}-\mathbf{0 . 4 8 2} * * * * \\
(0.000)\end{array}$ & $\begin{array}{l}-\mathbf{0 . 5 3 0} \text { ***** } \\
(0.000)\end{array}$ & $\begin{array}{l}-1.482 * * * * \\
(0.000)\end{array}$ & $\begin{array}{l}-1.365 * * * \\
(0.000)\end{array}$ & $\begin{array}{l}0.073 \\
(0.668)\end{array}$ & $\begin{array}{l}0.040 \\
(0.817)\end{array}$ & $\begin{array}{l}-0.278 \\
(0.626)\end{array}$ & $\begin{array}{l}-0.382 \\
(0.446)\end{array}$ & $\begin{array}{l}-1.207 * * * * \\
(0.000)\end{array}$ & $\begin{array}{l}-1.226 * * * * \\
(0.000)\end{array}$ \\
\hline Info. Asymmetry & $\begin{array}{l}-\mathbf{0 . 0 0 2} * * \\
(0.016)\end{array}$ & $\begin{array}{l}-\mathbf{0 . 0 0 2} * * \\
(0.014)\end{array}$ & $\begin{array}{l}-\mathbf{- 0 . 0 0 3}^{* *} \\
(0.016)\end{array}$ & $\begin{array}{l}-\mathbf{0 . 0 0 2 * *} \\
(0.027)\end{array}$ & $\begin{array}{l}-\mathbf{0 . 0 0 5 * *} \\
(0.035)\end{array}$ & $\begin{array}{l}-\mathbf{0 . 0 0 4 *} \\
(0.081)\end{array}$ & $\begin{array}{l}-\mathbf{0 . 0 0 4 * *} \\
(0.037)\end{array}$ & $\begin{array}{l}-\mathbf{0 . 0 0 7 * * *} \\
(0.045)\end{array}$ & $\begin{array}{l}-0.001 \\
(0.807)\end{array}$ & $\begin{array}{l}-0.003 \\
(0.768)\end{array}$ & $\begin{array}{l}\mathbf{0 . 0 0 9 * * * *} \\
(0.000)\end{array}$ & $\begin{array}{l}\text { 0.011**** } \\
(0.000)\end{array}$ \\
\hline Volatility & $\begin{array}{l}-\mathbf{0 . 0 0 7 * * * *} \\
(0.003)\end{array}$ & $\begin{array}{l}-\mathbf{0 . 0 0 8} * * * * \\
(0.000)\end{array}$ & $\begin{array}{l}-\mathbf{0 . 0 1 0} 0^{* * * * *} \\
(0.002)\end{array}$ & $\begin{array}{l}-\mathbf{0 . 0 1 1} \text { ***** } \\
(0.000)\end{array}$ & $\begin{array}{l}0.000 \\
(0.983)\end{array}$ & $\begin{array}{l}-0.004 \\
(0.382)\end{array}$ & $\begin{array}{l}\mathbf{0 . 0 1 7 * * * *} \\
(0.004)\end{array}$ & $\begin{array}{l}\mathbf{0 . 0 1 9} * * * * \\
(0.001)\end{array}$ & $\begin{array}{l}-\mathbf{0 . 0 3 5 * * *} \\
(0.010)\end{array}$ & $\begin{array}{l}-0.037 \\
(0.115)\end{array}$ & $\begin{array}{l}0.006 \\
(0.444)\end{array}$ & $\begin{array}{l}0.007 \\
(0.369)\end{array}$ \\
\hline Mkt Excess Return & $\begin{array}{l}-0.000 \\
(0.558)\end{array}$ & -- & $\begin{array}{l}-\mathbf{- 0 . 0 0 6}^{* * * * *} \\
(0.001)\end{array}$ & -- & $\begin{array}{l}\mathbf{0 . 0 0 9 * * * *} \\
(0.000)\end{array}$ & -- & $\begin{array}{l}0.001 \\
(0.575)\end{array}$ & --- & $\begin{array}{l}\mathbf{0 . 0 1 9 *} \\
(0.081)\end{array}$ & -- & $\begin{array}{l}0.000 \\
(0.738)\end{array}$ & -- \\
\hline Aggregate Liquidity & -- & $\begin{array}{l}\mathbf{4 . 6 3 1} \text {.**** } \\
(0.000)\end{array}$ & -- & $\begin{array}{l}\mathbf{8 . 6 6 0} * * * * \\
(0.000)\end{array}$ & --- & $\begin{array}{l}\text { 4.518*** } \\
(0.023)\end{array}$ & --- & $\begin{array}{l}-\mathbf{7 . 9 6 1 * * * *} \\
(0.000)\end{array}$ & --- & $\begin{array}{l}-7.192 \\
(0.423)\end{array}$ & --- & $\begin{array}{l}-3.399 \\
(0.139)\end{array}$ \\
\hline Information criteria & & & & & & & & & & & & \\
\hline Numbers of Obs. & 7440 & 7440 & 4410 & 4410 & 1215 & 1215 & 780 & 780 & 75 & 75 & 930 & 930 \\
\hline Num. of Cross-sec. & 1488 & 1488 & 882 & 882 & 243 & 243 & 156 & 156 & 15 & 15 & 186 & 186 \\
\hline Numbers of Ins. & 18 & 18 & 18 & 18 & 18 & 18 & 18 & 18 & 18 & 18 & 18 & 18 \\
\hline Wald $\mathrm{Chi}^{2}$ & $\begin{array}{l}\mathbf{8 7 . 6 8 * * * *} \\
(0.000)\end{array}$ & $\begin{array}{l}\text { 110.61**** } \\
(0.000)\end{array}$ & $\begin{array}{l}\mathbf{4 1 . 9 4} * * * \\
(0.000)\end{array}$ & $\begin{array}{l}\text { 103.6**** } \\
(0.000)\end{array}$ & $\begin{array}{l}\mathbf{5 4 . 0 8}^{* * * *} \\
(0.000)\end{array}$ & $\begin{array}{l}\mathbf{5 0 . 9 7 * * * *} \\
(0.000)\end{array}$ & $\begin{array}{l}\mathbf{1 2 . 6 0} * * \\
(0.013)\end{array}$ & $\begin{array}{l}\text { 19.66**** } \\
(0.000)\end{array}$ & $\begin{array}{l}\mathbf{2 2 . 0 8}^{* * * *} \\
(0.000)\end{array}$ & $\begin{array}{l}\mathbf{1 6 . 4 4} * * * \\
(0.002)\end{array}$ & $\begin{array}{l}\mathbf{5 1 . 2 9} * * * * \\
(0.000)\end{array}$ & $\begin{array}{l}\mathbf{6 5 . 2 4} * * * * \\
(0.000)\end{array}$ \\
\hline
\end{tabular}

P-values are in brackets. *, **, ***: significance levels of $10 \%, 5 \%$ and $1 \%$ respectively. Numbers of Obs.: Numbers of observations. Num. of Cross-sec.: Numbers of Cross-sections. Numbers of Ins.: Numbers of Instruments. 


\section{References}

Arellano, M., \& Bond, S., 1991. Some tests of specification for panel data: Monte Carlo evidence and an application to employment equations. Review of Economic Studies, 58, pp. 277-297.

Arellano, M., \& Bover, O., 1995. Another Look at the Instrumental Variable Estimation of Error Component Model. Journal of Econometrics, 68, pp. 29-52.

Asongu, S. A., Koomson, I.,\& Tchamyou, V. S., 2017. Financial Globalisation Uncertainty/Instability Is Good for Financial Development. Research in International Business and Finance, 41 (October), pp. 280-291.

Barro, R. J., \& Sala-i-Martin, X., 1992. Convergence. Journal of Political Economy, 100(2), pp. 223-251.

Benos, E., Jochec, M. \& Nyekel, V., 2010. Can mutual funds time risk factors? The Quarterly Review of Economics and Finance, 50(4), pp.509-514.

Bodson, L., Cavenaile, L. \& Sougné, D., 2013. A global approach to mutual funds market timing ability. Journal of Empirical Finance, 20, pp.96-101.

Bollen, N.P.B. \& Busse, J.A., 2001. On the Timing Ability of Mutual Fund Managers. Journal of Finance, 56(3), pp.1075-1094.

Bond, S., Hoeffler, A., \& Tample, J., 2001. GMM Estimation of Empirical Growth Models. University of Oxford, Oxford.

Blocher, J., 2014. Network Externalities in Mutual Funds. PhD Thesis, p 4.

Blocher, J., 2013. Peer Effects in mutual funds. PhD Thesis.

Busse, J.A., 1999. Volatility Timing in Mutual Funds: Evidence from Daily Returns. Review of Financial Studies, 12(5), pp.1009-1041.

Cao, C., Simin, T.T. \& Wang, Y., 2013. Do mutual fund managers time market liquidity? Journal of Financial Markets, 16(2), pp.279-307. 
Carhart, M.M., 1997. On Persistence in Mutual Fund Perfomance. Journal of Finance, 52(1), pp.57-82.

Chang, E., \& Lewellen, W., 1984. Impact of size and flows on performance for funds of hedge funds. Journal of Business, 57 (1), pp.57-72.

Clare, A., Ferguson, N., Sherman, M., \& Thomas, S., 2016. Multi-asset class mutual funds: Can they time the market? Evidence from the US, UK and Canada. Research in International Business and Finance, 36 (2016) 212-221.

Dai, Y., Kong, D. \& Wang, L., 2013. Information asymmetry, mutual funds and earnings management: Evidence from China. China Journal of Accounting Research, 6(3), pp.187-209.

Dierkens, N., 1991. Information Asymmetry and Equity Issues. Journal of Financial and Quantitative Analysis, 26(2), pp.181-199.

Elton, E.J., Gruber, M.J. \& Blake, C.R., 2011. An examination of mutual fund timing ability using monthly holdings data. Review of Finance, 16(3), pp.619-645.

Fabozzi, F.J., Focardi, S.M. \& Jonas, C., 2010. Investment Management after the Global Financial Crisis, Research Foundation of CFA Institute.

Fama, E., \& French, K. 1993. Common risk factors in the returns on stocks and bonds. Journal of Financial Economics, 33, pp.3-56.

Fama, E., \& French, K., 1992. The cross-section of expected stock returns. Journal of Finance, 47 (2), pp.427-465.

Ferson, W.E., \& Schadt, R.W., 1996. Measuring fund strategy and performance in changing economic conditions. Journal of Finance, 51, pp.425-461.

Frijns, B., Gilbert, A. \& Zwinkels, R.C.J., 2013. Market timing ability and mutual funds: a heterogeneous agent approach. Quantitative Finance, 13(10), pp.1613-1620.

Henriksson, R.D., 1984. Market Timing and Mutual funds perfomance: An Empirical Investigation. Journal of Business, 57(1, Part 1), pp.73-96. 
ICI, 2014. Recent Mutual Fund Trends, In A Review of Trends and Activities in the U.S. Investment Company Industry, (54th Edition 2014) Investment Company Fact Book,: Chapter 2: pp. 25-52 ; Investment Company Institute.

Islam, N., 2003. What have we learnt from the convergence debate?. Journal of Economic Surveys, 17(3), pp. 309-362.

Islam, N., 1995. Growth Empirics: A Panel Data Approach. The Quarterly Journal of Economics, 110(4), pp.1127-1170.

Ivashina, V., 2009. Asymmetric information effects on loan spreads. Journal of Financial Economics, 92(2), pp.300-319.

Jiang, G., Yao, T., \& Yu, T., 2007. Do mutual funds time the market? Evidence from portfolio holdings. Journal Financial Economics, 86 (3), pp.724-758.

Kacperczyk, M., Nieuwerburgh, S.V.A.N. \& Veldkamp, L., 2014. Time-Varying Fund Manager Skill. Journal of Finance, 69(4).

Kangoye, T., 2013. Does aid unpredictability weaken governance? Evidence from developing countries. Developing Economies, 51(2), pp.121-144.

Kitagawa, N. \& Okuda, S., 2013. Management Forecasts , Idiosyncratic Risk , and Information Envionment. Working Paper, 38, pp.1-44.

Kon, S.J., 1983. The market timing performance of mutual fund managers. Journal of Business, 56(3), pp.323-347.

Lee, C. \& Rahman, S., 1990. Market timing, selectivity, and mutual fund performance: an empirical investigation. Journal of Business, 63 (2), 261-278.

Lu, C.-W., Chen, T.-K. \& Liao, H.-H., 2010. Information uncertainty, information asymmetry and corporate bond yield spreads. Journal of Banking \& Finance, 34(9), pp.2265-2279.

Mitchell, T., (2004). The Middle East in the Past and Future of Social Science. David Szanton (ed.), The Politics of Knowledge: Area Studies and the Disciplines (University of California Press; Berkeley), pp. 74-118. 
Morningstar, 2014. The Morningstar Global Category Classifications. Morningstar Methodology Paper Effective as of April 30, 2014.

Pástor, L. \& Stambaugh, R.F., 2003. Liquidity Risk and Expected Stock Returns. The Journal of Political Economy, 111(3), pp.642-685.

SEC, 2008. Mutual Funds - A Guide for investors. U.S. Securities and Exchange Community.

Tchamyou, V. S. \& Asongu, S. A., 2017. Conditional Market Timing in the Mutual Fund Industry. Research in International Business and Finance. 42 (December), pp. 13551366.

Treynor, J., \& Mazuy, K., 1966. Can mutual funds outguess the market? Harvard Business Review, 44 (4), pp.131-136. 


\section{Appendix 1}

Table

\begin{tabular}{|c|c|c|c|}
\hline \multicolumn{4}{|c|}{ Definition of Variables } \\
\hline Variables & Signs & Definitions & Sources \\
\hline Market timing & Beta & Measure of systematic risk. & Computed \\
\hline $\begin{array}{l}\text { Information } \\
\text { Asymmetry }\end{array}$ & $\begin{array}{l}\text { Info. Asymmetry } \\
\text { (IA) }\end{array}$ & $\begin{array}{l}\text { Standard deviation of the idiosyncratic risk of individual } \\
\text { return. }\end{array}$ & Computed \\
\hline Volatility & Vol. & $\begin{array}{l}\text { Measure of dispersion of return (or uncertainty) of a } \\
\text { security. }\end{array}$ & Computed \\
\hline Market Excess Return & Mkt Excess Return & $\begin{array}{l}\text { Difference between the return of the market and the risk } \\
\text { free rate. }\end{array}$ & \\
\hline Size & SMB & Small [market capitalization] Minus Big. & Kenneth French's website \\
\hline Book-to-market & HML & High [book-to-market ratio] Minus Low. & \\
\hline Aggregate Liquidity & Agg.Liq. & $\begin{array}{l}\text { "Our monthly aggregate liquidity measure is a cross- } \\
\text { sectional average of individual- stock liquidity } \\
\text { measures"(Pástor and Stambaugh, 2003, p.643). }\end{array}$ & $\begin{array}{l}\text { Robert } \\
\text { Website }\end{array}$ \\
\hline
\end{tabular}

\section{Mutual fund categories}

\section{Variables}

Equity

Fixed-income

Allocation

Tax-preferred

Alternative

\section{Definitions}

"Global equity portfolios invest in companies domiciled in developed countries throughout the world. Some of these portfolios may include emerging market countries".(p.9)

"Global fixed income portfolios invest in fixed income securities from countries domiciled in developed countries throughout the world. Some of these portfolios may include fixed income securities of emerging market countries".(p.20)

"Allocation portfolios seek to provide both capital appreciation and income by investing in three major areas: stocks, bonds, and cash. While these portfolios explore the whole world, most of them focus on the U.S., Canada, Japan, and the larger markets in Europe. These portfolios typically have at least $10 \%$ of assets in bonds and less than $70 \%$ of assets in stocks. ”(p.15)

"US municipal fixed income portfolios invest in US municipal bond securities. These funds may invest nationally, or they may invest primarily in one single state". (p.25)

"Alternative funds may take short positions or invest in currencies, derivatives, or other instruments. Funds in this group may attempt to move in the opposite direction of the market or may have performance that is not correlated with the broader markets".

\section{Source}

Morningstar 